\title{
Sustainable Development Agendas in African Investment Treaties: Reconciling Principle with Practice
}

\author{
Collins C Ajibo \\ Faculty of Law, University of Nigeria \\ collins.c.ajibo@gmail.com
}

\begin{abstract}
Sustainable development has become the catchword for a sustainable standard of living, evidenced in the elaboration and elucidation of the principles by the United Nations Sustainable Development Goals (SDGs). African countries are deeply implicated in the sustainable development agendas as they strive to turn the tide in favour of a better way of living. Sustainable development is deeply intertwined with the natural resources sector because of its inextricable link with development imperatives. Despite a commitment to implement the sustainable development agendas in their various national laws, BITs, and regional and multilateral treaties, evidence indicates a divergence between principles and practice in Africa. Most African countries observe the principles in breach, illustrated by wide scale poverty, low human development, and environmental devastation of ecosystem and marine habitat. Arguably, African countries have an obligation to reflect the principles of sustainable development to which they committed themselves to ensure sound environmental governance and social equity.
\end{abstract}

\section{Introduction}

The concept of sustainable development has featured in significant number of international instruments and forums (Centre for International Sustainable Development Law [CISDL], 2005), often worded slightly different but reflecting a common theme, even if operationalised differently due to contextual disparities. The historical evolution of the principles of sustainable development can be said to have climaxed in the promulgation of the 2015 United Nations (UN) sustainable development goals (SDGs) (United Nations, 2015), which replaced the millennium development goals (MDGs). Nevertheless, prior to the emergence of the UN SDGs, states were still committed to observance of the precepts of sustainable development in numerous instruments (United Nations, 1992; UNESCO, 1992). Moreover, 
free trade agreements (FTAs) and international investment agreements (IIAs), and particularly bilateral investment treaties (BITs), bore the imprints of sustainable development agendas. African countries subscribe to numerous international instruments including BITs embodying provisions that require the observance of the principles of sustainable development (United Nations Development Programme [UNDP]). There is also a case for African investment facilitation measures to be structured in a manner that fosters sustainable development (Mbengue 2018).

Most African countries prioritise economic activities in the natural resources sector as the mainstay of their economy and revenue-generation base over governance for sustainable development. Despite its incorporation in documents approved at the highest political level, the commitment to sustainable development agendas is practically illusory in most Africa countries. This has raised questions about the disposition of African countries to concretise the principles of sustainable development to which they have willingly acceded in numerous treaties and instruments. Rather than promote social equity, environmental sustainability and human rights, the exploitation of natural resources in most African countries is fuelling general discontent, environmental genocide, and repression. The analysis of sustainable development agendas in the African natural resources sector frequently leads to pejorative characterisation as the 'resource curse' or the 'paradox of penury amidst plenty'(Constantinescu 2015, p. 1), indicating that significant financial outcome from the exploitation of natural resources has not yielded significant developmental outcomes (United Nations Conference on Trade and Development [UNCTAD] 2015, p. 6). More often than not, African elites use financial accrual from the exploitation of natural resources exclusively to strengthen their political and economic interests to the detriment of the greater proportion of the population. This in turn fuels discontent, disenchantment and disillusionment which eventually can metamorphose into armed conflict. Arguably, there needs to be a paradigm shift in policy and practice.

This paper continues the debate on the need for African countries to reflect sustainable development agendas in the exploitation of natural resources. It contends that African countries have an obligation to concretise in their various jurisdictions the sustainable development agendas to which they willingly subscribed in national and international instruments in order to foster social equity and sound environmental governance. Given the broad contour of the SDGs, this paper will be restricted to evaluation of the scope of compliance with sound environmental governance, social equity and social responsibility which also coalesce with the realities of the Africa BITs 
treaty making. Nevertheless, since '[a]11 17 Goals interconnect, meaning success in one affects success for others' (UNDP), reference will be made to other aspects of the SDGs. The focal point will be the natural resources sector or extractive industries given that most African countries depend on the sectors for sustenance and development (African Development Bank, 2015; 2016, p. 3).

Following this introduction, the first section assesses the general framework of sustainable development. The following section examines the sustainable development agendas in African treaties; then the paper examines the scale and scope of the sustainable development agendas in African regional trade and investment groupings; then the paper discusses the not lowering of standards clause, following by a discussion of corporate social responsibility; then the next section examines reconciling principle with practice and evaluates the level of conformity between the principles of sustainable development encapsulated in many instruments and practice. The paper will then conclude.

\section{General Framework of Sustainable Development}

The concept of sustainable development lacks overarching definition. Nevertheless, the World Commission on Environment and Development: Our Common Future (the Brundtland Report) is constantly cited as providing an authoritative definition. The Brundtland Report viewed sustainable development as development that meets the needs of the present without compromising the ability of future generations to meet their own needs (United Nations, 1987; United Nations Commission on Sustainable Development, 2007). Although this definition is clearly ambitious, it is 'relatively unhelpful when it comes to providing clues for the legal characterisation of the notion' of sustainable development (Barral 2012, pp. 377-378). The UN classified SDGs into seventeen broad categories, which provides further clues to the wide reach of the precepts of sustainable development.

The primary responsibility for the enforcement of SDGs generally lies with the state. However, non-state actors such as the transnational corporations (TNCs) or multinational corporations (MNCs) play important roles in reflecting global best practices in the area of operation. More particularly, MNCs have an obligation to comply with the host laws, particularly environmental laws, human right law and labour law, which in totality overlap with the precepts of sustainable development. A high proportion of MNCs have adopted 'triple bottom line' business strategies that 
are consonant with the definition offered by the Brundtland Report (Weaver 2003, pp. 2-3). The 'triple bottom line' strives to achieve three crucial benchmarks reflected in '[c] orporate economic growth, as measured in terms of revenues, earnings, and shareholder return'; [c]orporate environmental stewardship, as measured in terms of increased energy efficiency, pollution reductions, and mitigation projects'; and '[c]orporate social progress, measured in terms of community outreach, human rights, labor standards, respecting diversity in the workplace, and preventing conflicts' (Weaver 2003, pp.2-3).

The triple bottom line is strengthened in the definition of sustainable development by the UNDP and the World Energy Council in their World Energy Assessment as "energy produced and used in ways that support human development over the long term, in all its social, economic, and environmental dimensions' (UNDP 2000, p.3). Some MNCs operating in the oil and gas sector have also tended to assimilate the seventeen SDGs into different phases of oil and gas operations from upstream, midstream, to downstream sectors, and from offshore to on-shore operations (UNDP 2017).

The SDGs are closely related and a contribution to one SDG effectively impacts other SDGs, and any significant progress on one SDG correlates with progress on others (UNDP 2017, p. 4). Emphasising the interrelationship that underlines the SDGs, the UNDP said of climate change that, despite being a stand-alone goal,

it has implications for all 17 SDGs and so addressing it is a consideration when approaching each goal. Climate change may disproportionately affect the poor and most vulnerable, undermining efforts to end poverty (SDG1), achieve gender equality (SDG5), and reduce inequality among and within countries (SDG10). Climate change can threaten food security (SDG2), increase stress on water resources (SDG6), alter ecosystems and damage biodiversity (SDG14 and 15). It may also change the distribution patterns of infectious diseases and so affect global health (SDG3). All these impacts may threaten peace and security (SDG16). At the same time, the response to climate change can also drive progress on other SDGs, for example by promoting improved energy efficiency and investment in renewable energies and technologies (SDG7), which can open up new economic opportunities (SDG8) (UNDP 2017, p. 9). 
In short, sustainable development can be thought of as an interstitial norm that tends to reconcile other conflicting norms, related to the economy, environment, and social development, with a pull on judicial process (Lowe 1999 , p. 19). Though the preceding points may cast sustainable development as an integrative norm rather than a self-standing legal taxonomy, it does situate it within the realm of legal discourse cemented by judicial legitimacy (Case Concerning the Gabcikovo-Nagymaros Dam). In the Arbitral Award for Arbitration Regarding the Iron Rhine ('Ijzeren Rijn') Railway, the Permanent Court of Arbitration reiterated this fact when it emphasised that,

[e]nvironmental law and the law on development stand not as alternatives but as mutually reinforcing, integral concepts, which require that where development may cause significant harm to the environment, there is a duty to prevent, or at least mitigate such harm.... This duty, in the opinion of the Tribunal, has now become a principle of general international law. This principle applies not only in autonomous activities but also in activities undertaken in implementation of specific treaties between the Parties.

Even so, the right of states to enforce sustainable development agendas vis a vis obligations assumed in IIAs remains contested in the context of investment arbitration. This is illustrated by the case of Compañia del Desarrollo de Santa Elena S.A. v. Republic of Costa Rica, which relates to environmental regulatory measure undertaken by the government to protect the rainforest zone in conformity with biodiversity conservation law. The tribunal while finding for the investor (claimant) noted inter alia that,

[e]xpropriatory environmental measures - no matter how laudable and beneficial to society as a whole - are, in this respect, similar to any other expropriatory measures that a state may take in order to implement its policies: where property is expropriated, even for environmental purposes, whether domestic or international, the state's obligation to pay compensation remains.

This ruling was subsequently echoed and relied upon by the arbitral tribunal in the case of Tecmed $v$ Mexico. ${ }^{1}$ In that case, the tribunal noted that

1 TecnicasMedioambientalesTecmed, S.A. v United Mexican States (ICSID Case No. ARB (AF)/00/2), Award of May 29, 2003, para. 121, at 46. 
the host state would still be liable irrespective of the fact that it is exercising its inherent regulatory powers that are beneficial to the whole society including environmental regulation so long as investors' interest is affected. Accordingly, whether the action of the host state constitutes a legitimate regulatory exercise of power or not it can still amount to de facto expropriation if it affects foreign investments. ${ }^{2}$ Similarly, in the case of $C M S$ Gas Transmission Coy v Argentina, ${ }^{3}$ subsequently reaffirmed in the case of Vivendi Universal S. A. v Argentina, ${ }^{4}$ the tribunal noted that the host state could be liable for breach of 'Fair and Equitable Treatment', irrespective of the fact the resultant action is unintentional and devoid of bad faith.

These rulings acknowledge neither the legitimate expectation of the host state in concluding IIAs (Ngangjoh-Hodu \& Ajibo 2018, p. 45) nor the regulatory prerogatives of the host government to cater for the welfare of the people (Ajibo 2013, p. 382; Ajibo \& Nwafor 2017, p. 199). Hence, the structural framework of the investment arbitration and the legitimacy of its norm setting are increasingly being questioned (Ngangjoh-Hodu \& Ajibo 2015 , p. 1). Thus, the generation of norms of investment protection should not override the obligations of state to enforce public welfare including the sustainable development agendas (Ajibo 2018, p. 77).

\section{Sustainable Development Agendas in Africa Investment Treaties}

Evidence from treaty-making indicates a mixed approach to the incorporation of sustainable agendas in investment treaties of most capital exporting countries. In reality, the term 'sustainable development' is not always used in the treaties. Rather, terms with similar implication are used instead, such as a "not lowering standards clause" (NLSC), corporate social responsibility (CSR) or other terms requiring respect for environment, human rights, labour rights and positive corporate image. While some Model BITs incorporate sustainable development principles, others do not. Some of the Model BITs that incorporate sustainable development principles, among the major capital exporting jurisdictions, include the 2012 US Model BIT, the Canada's Model BIT and Norway Model BIT.

2 Tecnicas Medioambientales Tecmed, S.A. v United Mexican States (ICSID Case No. ARB (AF)/00/2), Award of May 29, 2003, para. 116, at 44.

${ }^{3}$ CMS Gas Transmission Coy v Argentina, ICSID Case No. ARB/01/8, Award of May 12,2005 , para.280 at 82 .

${ }^{4}$ Vivendi Universal S. A. v Argentina, ICSID Case No. ARB/97/3, Award of August 20, 2007, para. 7.4.12. 
The 2016 Pan-African Investment Code is a distinctive investment instrument that is poised to 'promote, facilitate and protect investments that foster sustainable development' (UNECA 2016). The Pan African Investment Code is indeed epoch-making in treaty making because of the requirements placed on the host states and a schedule of explicit obligations required of investors. For instance, investors have obligations to ensure sound corporate governance, adhere to socio-political obligations, eschew bribery and corruption in dealings, incorporate CSR practices in areas of operation, reflect the sustainable exploitation and use of natural resources, and align business with human rights. Further, investors are required to ensure the transfer of technology for development and that such technology should be conducive to the environment. The African Investment Code appears to be the first regional instrument to embody strong pro-host state provisions on development. Still, the pro-host state provisions are not unprecedented. The UN Code of Conduct on TNCs - that never came into force - embodies similar provisions that favour host state development. The African Investment Code constitutes a model for investment agreements concluded by African countries and it is the responsibility of African countries to reflect this course of treaty making. Similarly, the concluded African Continental Free Trade Area (AfCFTA) agreement incorporates a raft of provisions on fostering sustainable development.

However, there could be disparity between the provisions on the principles and actual treaty practice. African countries have concluded quite a significant number of IIAs with both the capital exporting countries and the capital importing countries. But, as shown below, only Canada has shown real inclination to incorporate sustainable development principles in BITs concluded with African countries. Canada's treaty practice indicates the incorporation of provision on CSR despite its non-incorporation in the Model BIT. It should be pointed out that African countries equally have an obligation to insist on the incorporation of sustainable development principles in the BITs they conclude. To assess the BITs concluded by African countries, we next examine the scale and scope of the sustainable development agendas in African regional trade and investment groupings.

\section{Sustainable development agendas in African regional trade and investment groupings}

African regional trade and investment groupings are partly motivated by social, cultural and political interests and reflect geographical particularities. 
Evolving realities indicate a measured approach to the incorporation of sustainable development agendas in African regional groupings.

The preamble of treaty establishing the East Africa Community (EAC) states the determination of the signatories to 'strengthen their economic, social, cultural, political, technological and other ties for their fast, balanced and sustainable development'. Article 5 of the treaty similarly incorporates sustainable development agendas including a commitment of the parties to 'the promotion of sustainable utilisation of the natural resources of the Partner States and the taking of measures that would effectively protect the natural environment of the Partner States'.

The preamble to the treaty establishing the Common Market for Eastern and Southern Africa (COMESA) countries emphasises the undertaking of the signatories to ensure 'the consolidation of their economic co-operation through the implementation of common policies and programmes aimed at achieving sustainable growth and development'. Article 3 of that treaty further embodies the parties' commitment to sustainable development agendas. Similar themes run through the other provisions, including chapter sixteen relating to the 'cooperation in the development of natural resources, environment and wildlife'.

Similarly, the preamble to the treaty establishing the Southern African Development Community (SADC) states in its preamble the determination of the signatories to alleviate poverty 'through deeper regional integration and sustainable economic growth and development'. Article 5 of the treaty incorporates sustainable development agendas and the SADC Model on investment agreements integrates the principles of sustainable development in its provisions.

The treaty establishing the Economic Community of Central African States (ECCAS) does not specifically use the term 'sustainable development' but reflects terms to such effect in its provisions. Article 4 of ECCAS emphasises the commitment of the parties to promote and strengthen a balanced and self-sustained development in all fields of economic and social activity in order to raise the standard of living of its peoples, increase and maintain economic stability, and contribute to the progress and development of the African continent.

The treaty establishing the Economic Community of West African States (ECOWAS) similarly does not clearly stipulate the commitment to sustainable development agendas. However, a closer look at the provisions shows the incorporation of principles convergent with sustainable development agendas. For instance, Article 3 emphasises the undertaking of 
the signatories to harmonise and coordinate policies for the protection of the environment in the course of the economic development of the region.

The treaty establishing the African Economic Community (AEC) takes cognisance of sustainable development principles. Article 58 reaffirms the commitment of the parties to promote a healthy environment in the course of natural resources exploration and exploitation. Correspondingly, African countries overwhelmingly subscribe to international instruments that promote sustainable development agendas at the highest political level such as the Stockholm Declaration, the Rio Declaration, the Johannesburg Declaration, and others, culminating in the UN SDGs.

Thus African countries subscribe to sustainable development agendas both regionally and multilaterally. We show below that similar scenarios are progressively playing out in BITs concluded by African countries, usually expressed as NLSC and/or CSR, or similar appellations. ${ }^{5}$

\section{Not lowering of standards clause (NLSC)}

A "not lowering standards clause" involves environmental, labour and human rights clauses that require 'a commitment to refrain from relaxing domestic environmental and labour legislation to encourage investment' (UNCTAD 2015; UNGA 2015), expressed either 'as a binding obligation or as a soft law clause' (UNCTAD 2012). NLSC drafting reflects the agreement of the parties that it is inappropriate to relax 'domestic health, safety or environmental measures or core labour standards' (Article 11 of Norway Model BIT), or simply 'domestic health, safety or environmental measures' (Article 11 of Canada Model BIT) to encourage investment.

The US Model BIT approaches the concept in the following way: 'Investment and Environment' (Article 12 of the US Model BIT), emphasising environmental sustainability, and 'Investment and Labor' (Article 13 of the US Model BIT), requiring labour rights protection in accordance with International Labor Organization (ILO) and national labour law. However drafted, the objectives are clear: a reaffirmation that investment should not derogate from the commitments to international agreements and national laws relating to environmental standards, health standards, safety, labour rights and human rights. Earlier US BITs with African countries prior to 2012 Model BIT did not specifically recognise the NLSC provision except the US-Rwanda BIT of 2012 which makes

\footnotetext{
${ }^{5}$ Note that the NLSC and CSR provisions examined are those written in English and accessible, given that some BITs were available but not written in English while others were unavailable for viewing online.
} 
provisions on 'investment and environment' (Article 12 of US-Rwanda BIT) and 'investment and labor' ( Article 13 of US-Rwanda BIT).

In addition to its incorporation in the Model BIT (Article 11 of Canada Model BIT), Canada's treaty practice with African countries reflects recognition of the NLSC provisions. The BITs applicable include the following, all in Article 15: Canada-Benin BIT of 2014; Canada-Burkina Faso BIT of 2015; Canada-Cameroon BIT of 2016; Canada-Cote d'Ivoire BIT of 2015; Canada-Guinea BIT of 2015; Canada-Mali BIT of 2016; Canada-Nigeria BIT of 2014; Canada-Senegal BIT of 2016; CanadaTanzania BIT of 2013. The Canada-Egypt BIT of 1997 and the CanadaSouth Africa BIT of 1995 do not specifically include the NLSC provision but contain exceptions (Articles XVII in each case) that allow the parties regulatory discretion, particularly environmental regulation. This could be explained by the fact that the two BITs partly belong to older generation of Canadian BITs practice.

Though China's Model BIT and BITs practice do not generally disclose sensitivity to the emerging standards, Article 11 of the China-Mauritius BIT of 1996 and Article 10 of the China-Tanzania BIT of 2013 incorporated the principle. The China-Mauritius BIT fused the prerogatives of the state to protect essential security interests, usually drafted in separate provision, with NLSC provision. But the China-Tanzania BIT lays out elaborate provisions on NLSC reminiscent of Western-oriented BIT model and treaty practice.

Furthermore, the Nigeria-Austria BIT stipulates the commitment of the parties to "to achieving these objectives in a manner consistent with the protection of health, safety, and the environment, and the promotion of internationally recognised labour standards'. The Cameroon-Turkey BIT provides that parties are 'convinced that the objectives [of the BIT] can be achieved without relaxing health, safety and environmental measures . . . as well as internationally recognised labor rights'. Thus, African BITs practice increasingly indicates the observance of the principles of sustainable development, partly reflected in the incorporation of the NLSC.

\section{Corporate Social Responsibility (CSR)}

Most Model BITs of the major capital exporting countries do not incorporate CSR provisions but there are emerging trends towards the inclusion of CSR in BITs practice. The Nigeria-Austria BIT preamble affirms the parties' 'belief that responsible corporate behaviour can contribute to mutual confidence between enterprises and host countries' (Willard \& Morreau 2015). Canada however leads the way in the 
incorporation of the CSR provision in addition to NLSC provision. Though the Canada's 2004 Model BIT does not incorporate a CSR requirement, Canada has voluntarily included CSR provision in its BITs practice with African countries. With the exceptions of the Canada-Egypt BIT of 1997, the Canada-South Africa BIT of 1995 and the Canada-Tanzania BIT of 2013, recent Africa-Canada's BITs contain this provision. They include CanadaCameroon ( 2016), Canada-Cote d'Ivoire (2015), Canada-Guinea (2015), Canada-Mali ( 2016), Canada-Nigeria (2014), and Canada-Senegal ( 2016). The language and content of all the relevant BITs present a common pattern and theme to the effect that each party,

should encourage enterprises operating within its territory or subject to its jurisdiction to voluntarily incorporate internationally recognised standards of corporate social responsibility in their practices and internal policies, such as statements of principle that have been endorsed or are supported by the Parties. These principles address issues such as labour, the environment, human rights, community relations and anti-corruption.

The Canada-Senegal BIT not only incorporates the preceding but also an additional sentence noting that '[s] uch enterprises are encouraged to make investments whose impacts contribute to the resolution of social problems and preserve the environment'.

One common approach that underlies all the CSR provisions is the nonidentification of any particular CSR principles or standards that a party should encourage. The implication is that the parties are free 'to choose their own CSR standards' (Willard and Morreau 2015). Despite this, the current Canada-African BITs practice 'reflect a growing trend to address social and environmental issues in investment treaties' (Willard and Morreau, 2015).

The incorporation of CSR provision is clearly an emerging innovation, and it seems to reflect the future direction of treaty-making. It is important that African countries consider Canada's treaty practice with African countries as an irreducible template. The drafting of CSR provision occasionally shows aspirational language and soft law disposition. This will make implementation daunting for African countries because of peculiar institutional challenges and corruption. Hence, the obligation to reflect CSR standards should be consistent with other obligations under the substantive part. 


\section{Reconciling Principle with Practice}

The significance of sustainable development agendas is no less relevant in the natural resources sector as in any other sector. But the abundance of natural resources in itself does not transform automatically into sustainable standards of living. In Africa, as the UNDP has noted (2014, p. 1), while the development of the extractive industries,

holds the promise of raising incomes, poverty can still persist; jobs may be hard to come by; the industry can be an 'enclave', having no links with local enterprises that could provide production inputs to it or consume its produce (backward/forward linkages); and the environment can be degraded while livelihoods are destroyed. The wealth pouring into the country can also breed corruption and raise inequalities. All of these unwanted outcomes may create fertile grounds for violence and conflict.

Indeed, the condition of many African countries shows that the continent lags behind the rest of the world in the achievement of substantive outcomes from sustainable development principles. This occurs despite their commitment to reflect the principles into practice. As shown above, there are copious provisions on sustainable development agendas in the national laws of African countries as well as supranational instruments they have acceded to such as bilateral, regional and multilateral treaties. But the prevalence of social unrest, economic stagnation, and environmental degradation in many resource-rich African countries arising from the exploitation of natural resources shows that the principles encapsulated in the African treaty practice have not been reali sed. Instances of the resource-rich African countries that cannot measure up to the UN SDGs benchmarks but rather are engulfed in strife or experiencing the aftermath of strife include Angola, the Central African Republic, the Democratic Republic of Congo, Liberia, Nigeria, Sierra Leone and Sudan (Constantinescu, 2015). Other countries outside this league are no better even if they are enjoying relative peace.

Despite being signatories to many international instruments that approve sustainable development agendas, most African countries observe the principles in breach. The 2016 Morocco-Nigeria BIT is often cited as being an epoch-making instrument because of the incorporation of sustainable development issues but it remains to be seen how it will be reflected in practice. 
Nigeria has been particularly notorious regarding deficits in sustainable development. The Niger-Delta region of the country continues to experience unprecedented levels of ecological devastation that affect the ecosystem and marine habitat. Apparently, the MNCs operating in the Niger-Delta region of Nigeria are making efforts to clean the environment and reflect social responsibility through the provision of scholarships and amenities to the host communities. But the scale of social deprivation and environmental devastation is not rivaled by the scale of MNCs' response and governmental interest. According to the United Nations Environment Programme (UNEP) report, the environmental restoration of Niger Delta region of Nigeria 'could prove to be the world's most wide-ranging and long term oil clean-up exercise ever undertaken if contaminated drinking water, land, creeks and important ecosystems such as mangroves are to be brought back to full, productive health' (UNDP, 2011a; 2011b). The report, which covered over 200 locations with over 4000 samples of oil and water, unraveled an unprecedented scale of ecological devastation and monumental health risk posed by the sub-optimal practices of the MNCs (UNDP, 2011a). The UNEP report constitutes just one in a continuum of systematic cases of environmental degradation and social inequity in the Niger-Delta region and other parts of Africa.

\section{Conclusion}

Sustainable development agendas evolved from numerous international instruments and culminated in the UN SDGs. African countries have acceded to numerous instruments embodying sustainable investment agendas bilaterally, regionally and multilaterally. Despite the incorporation of the principles, African countries continue to epitomise a continent lacking the will to realise sustainable development agendas, thereby giving vent to social unrest, environmental degradation, economic stagnation, insecurity and general underdevelopment. We have argued that African countries cannot continue to ignore the best practices around the world if they intend to develop socially, politically and economically.

\section{References}

African Development Bank. (2015). Draft African Natural Resources Center Strategy for 2015-20.www.afdb.org/en/documents/document/draftafrican-natural-resources-center-strategy-for-2015-2020-530 53022/ 
African Development Bank 'African Natural Resources Center'. (2016). https://www.afdb.org/fileadmin/uploads/afdb/Documents/Publication s/anrc/AfDB ANRC BROCHURE en.pdf

Ajibo, Collins C. (2013). 'Legitimacy Challenges in Investor-State Arbitration Interpretative Principles: Reflecting on a Balancing Tool'. Manchester Journal of International Economic Law, 10, 3, 382.

Ajibo Collins C. (2018). 'The Regional Courts and the Development of International Investment Law: the Case of NAFTA Chapter 11 Dispute Settlement and ECtHR'. Law \& Development Review, 11, 1, 77.

Ajibo Collins C and Ndubisi Nwafor. (2017). 'Jurisdictional Competence and Deferential Standard of Review in Investor-State Dispute Settlement: A Case for Balance of Prerogatives'. Manchester Journal of International Economic Law, 14, 2, 199.

Barral Virginie. (2012). 'Sustainable Development in International Law: Nature and Operation of an Evolutive Legal Norm, EJIL, 23, 2, 377378.

Case Concerning the Gabcikovo-Nagymaros Dam (25 September 1997) (Hungary v Slovakia) I.C.J. Rep., 37 I.L.M. (1998) 162.

Centre for International Sustainable Development Law. (2005). 'What is Sustainable Development Law?' (2005), http://cisdl.org/public/docs/What\%20is\%20Sustainable\%20Develop ment.pdf

Compañia del Desarrollo de Santa Elena S.A. v. Republic of Costa Rica, ICSID Case No. ARB/96/1, Final Award of February 17, 2000, para.72, at 193 .

Constantinescu, Maria. (2015). 'Sustainable Exploitation of Natural Resources and National Security.' Acta Universitatis Danubius Economica, 11, 5, 1.

Lowe Vaughan. (1999). 'Sustainable Development and Unsustainable Arguments', in Alan Boyle and David Freestone (eds), International Law and Sustainable Development: Past Achievements and Future Challenges. Oxford: Oxford University Press.

Mbengue Makane Moïse. (2018). 'Facilitating investment for sustainable development: it matters for Africa'. Columbia Centre for Sustainable Development.http://ccsi.columbia.edu/files/2016/10/No-222Mbengue-FINAL.pdf

Ngangjoh-Hodu Yenkong and Collins C. Ajibo. (2015). 'ICSID Annulment Procedure and the WTO Appellate System: The Case for an Appellate 
System for Investment Arbitration' . Journal of International Dispute

Settlement, 6, 2, 1 .

Ngangjoh-Hodu Yenkong and Collins C. Ajibo. (2018). 'Legitimate

Expectation in Investor-State Arbitration: Re-contextualising a

Controversial Concept from a Developing Country Perspective.'

Manchester Journal of International Economic Law, 15, 1, 45.

Permanent Court of Arbitration: In the Arbitration Regarding the Iron Rhine

('Ijzeren Rijn') Railway, between the Kingdom of Belgium and the

Kingdom of the Netherlands (May 24, 2005) at 59, 114.

United Nations. (1987). 'Report of the World Commission on Environment and Development: Our Common Future', http://www.undocuments.net/our-common-future.pdf

United Nations. 'United Nations Conference on Environment and Development: Rio Declaration on Environment and Development' (1992) http://www.un.org/documents/ga/conf151/aconf15126-1anne x1.htm.

United Nations. Commission on Sustainable Development 'Framing Sustainable Development: The Brundtland Report - 20 Years On' (2007), http://www.un.org/esa/sustdev/csd/csd15/media/background er brundtland.pdf

United Nations. Economic Commission for Africa (2016). 'Draft PanAfrican investment code' https://repository.uneca.org/handle/10855/ 23009

United Nations. Educational, Scientific and Cultural Organization. (1992).

'The Rio Declaration on Environment and Development'. http://www.unesco.org/education/pdf/RIO E.PDF.

United Nations Conference on Trade and Development. (2012). 'Not lowering of Standards Clause' . Policy Options for International Investment Agreements, http://investmentpolicyhub.unctad.org/ipfsd/ section/3/toc-item-details/343

United Nations Conference on Trade and Development. (2015a). 'How can Energy Extractives Resources be used for Sustainable Development in Africa?' http://unctad.org/meetings/fr/Presentation/17OIL GASMINE\%20Mahaman\%20Lalouan\%20Gaya\%20S2.pdf

United Nations Conference on Trade and Development. (2015b). Investment policy framework for sustainable development (Geneva and New York).

United Nations Development Programme. (2000). 'The World Energy Assessment: Energy, and the Challenge of Sustainability'. http://www.undp.org/content/undp/en/home/librarypage/environment 
-energy/sustainable_energy/world_energy_assessmentenergyand thechallengeofsustainability.html

United Nations Development Programme. (2014). 'Extractive Industries for

Sustainable Development'. http://www.undp.org/content/dam/undp/ library/Poverty\%20Reduction/Extractive\%20Industries/Extractive-

Industries-Brochure.pdf

United Nations Development Programme. (2017). 'Mapping the Oil and Gas industry to the Sustainable Development Goals: An Atlas'. http://www.undp.org/content/undp/en/home/presscenter/articles/201 7/07/24/mapping-the-oil-and-gas-industry-to-the-sustainabledevelopment-goals.html

United Nations Development Programme. (2018). 'Sustainable Development Goals' http://www.undp.org/content/undp/en/home/ sustainable-development-goals/background.html.

United Nations Environment Programme. (2011a). 'UNEP Ogoniland Oil Assessment Reveals Extent of Environmental Contamination and Threats to Human Health', http://www.unep.org/disastersandconflicts /news/unep-ogoniland-oil-assessment-reveals-extent-environmentalcontamination-and-threats-human

United Nations Environment Programme 'Environmental Assessment of Ogoniland' (2011b), http://postconflict.unep.ch/publications/OEA/ UNEP OEA.pdf

United Nations General Assembly. (2015a). 'Resolution adopted by the General Assembly on 25 September 2015 - Transforming our World: the 2030 Agenda for Sustainable Development' Seventieth session Agenda items 15 and 116, UN/A/RES/70/1.

United Nations General Assembly. (2015b). 'Transforming our world: the 2030 agenda for sustainable development (2015)' adopted by the United Nations General Assembly on 25 September 2015, http://tinyurl.com/ndbuhro.

Weaver, Jacqueline L. (2003). 'Sustainable Development in the Petroleum Sector', in Adrian J Bradbrook and Richard L Ottinger (eds.), Energy Law and Sustainable Development.

Willard, Rainbow and Sarah Morreau. (2015). 'The Canadian Model BIT A Step in the Right Direction for Canadian Investment in Africa?' Kluwer Arbitration Blog, http://arbitrationblog.kluwerarbitration.com /2015/07/18/the-canadian-model-bit-a-step-in-the-right-direction-forcanadian-investment-in-africa/ 